\title{
Morphometric and Genetic Variation in Three Populations of Indian Salmon (Polydactylus plebeius)
}

\author{
Ramakrishnan THIRUMARAISELVI, Muthusamy THANGARAJ*, Vellaichamy RAMANADEVI \\ Annamalai University, Faculty of Marine Sciences, Centre of Advanced study in Marine Biology, \\ Parangipettai,TamilNadu,608 502, India; coralholder@yahoo.com ( ${ }^{*}$ corresponding author)
}

\begin{abstract}
Morphometric character analyses and RAPD was used to discriminate and ratify the status of three populations of Indian salmon, Polydactylus plebeius along the coromandel coast of India. Morphometric analyses showed a clear pattern of differentiation between the stocks and revealed the discreteness of two groups, southern stock (Pazhayar) and northern stock (Cuddalore). The univariate analysis of variance showed significant differences between means of the samples for most morphometric descriptors. A total of 1077 scorable bands were produced using all ten arbitrary primers in three populations. An un-weighted pair-group method with arithmetic mean (UPGMA) dendrogram was constructed based on genetic values to show the genetic relationship among the three populations. The genetic diversity $(\mathrm{H})$ of $P$. plebeius in Cuddalore was more $(0.0733 \pm 0.0648)$ than Pazhayar $(0.0609 \pm 0.0416)$ and Vellar $(0.0613$ $\pm 0.0344)$ populations. All the three populations had significantly $(p<0.001)$ higher interpopulation genetic distance value than the intrapopulation value. Further molecular studies, comprising more markers and populations are still required to precisely evaluate the genetic structure of threadfin fishes throughout the Indian coast.
\end{abstract}

Keywords: genetic variation, Indian salmon, morphometric, Polydactylus, population structure

\section{Introduction}

Threadfin fish belongs to the family Polynemidae, which forms part of the order Perciformes. They typically inhabit marine coastal waters, estuaries and freshwater river mouths. This family has a wide distribution in the tropical parts of Atlantic, Indian and Pacific Oceans (Kagwade, 1970). The potential annual yield of polynemids in India is estimated around 9,000 tones (Srinath and Balan, 2003). Present catch of polynemids have gone down mainly because of the introduction of shrimp trawlers which has destroyed most of the young-ones of the larger varieties of polynemids grow to more than a meter (Prasad et al., 2005).

Morphometric analysis has been applied to many stock differentiation and life-history problems in many fish species (Bronte et al., 1999). If shape differences in different populations of the same species can be used to discriminate morphotypes, they may also be useful in examining the stock structure within a morphotype (Joseph and Jayasankar, 2001). Detection of differences within a morphotype may indicate geographically separated stocks, whose shapes may be predicted on local environmental conditions or have genetic bases (Joseph and Jayasankar, 2001). They discriminate two Nemipterus populations through morphometric and meristic characters in India. Turan et al. (2006) reported the genetic and morphological variation of Pomatomus saltatrix throughout the Black Seas, Marmara, Aegean and eastern Mediterranean Seas.
Erguden et al. (2009) underwent morphometric and meristic analyses of chub mackerel Scomber japonicus to discriminate stocks throughout the Black, Marmara, Aegean, and northeastern Mediterranean Seas.

Genetic markers are generally oversensitive to a low level of gene flow, relatively low level of exchange between stocks, which are quite negligible from a management perspective, and may be sufficient to ensure genetic homogeneity (Carvalho and Hauser, 1994; Ward and Grewe, 1994). RAPDs have gained considerable attention particularly in population genetics (Lu and Rank, 1996), species and subspecies identification (Bardakci and Skibinski, 1994), phylogenetics, linkage group identification, chromosome and genome mapping, analysis of interspecific gene flow and hybrid speciation, and analysis of mixed genome samples (Hadrys et al., 1992), breeding analysis and as a potential marker for single-locus genetic fingerprints (Brown and Epifanio, 2003)

In finfishes, size and morphometric variations among populations continue to play an important role in stock identification, despite the advent of biochemical and molecular genetics technique which help in identification of genetic differences between groups (Swain and Foote, 1999). Considering the importance of morphometric, genetic variation and as there are no attempts to study in $P$. plebeius, in spite of its significant contribution in Indian marine fish landing the present study was undertaking. The objective of this study was to evaluate patterns of morphological and genetic variation in the Indian salmon, $P$. 
276

plebeius in three estuarine regions, by analyzing morphometric characters and banding pattern using ten arbitrary primers.

\section{Materials and methods}

\section{Sample collection}

The striped threadfin, P. plebeius were collected from three stations such as, (S1) Cuddalore estuary (Lat. 11 ${ }^{\circ} 42^{\prime}$ $\mathrm{N}$; Long. $74^{\circ} 46^{\prime} \mathrm{E}$ ), (S2) Vellar estuary (Lat. $11^{\circ} 29^{\prime} \mathrm{N}$; Long. $79^{\circ} 46^{\prime} \mathrm{E}$ ) and (S3) Pazhayar estuary (Lat. $11^{\circ} 21^{\prime}$ $\mathrm{N}$; Long. $79^{\circ} 49^{\prime} \mathrm{E}$ ) given in Fig. 1. Totally fifty individuals from each station were sampled for morphometric character measurements and tissue samples DNA isolation.

\section{Morphometrics}

Forty nine morphometric characters were measured as per earlier report (Motomura et al., 2001) and used for further analysis. The morphometric data were analysed using sheared PCA as per Bookstein et al. (1985). This technique, which quantifies shape differences independent of size, as previously been used to distinguish fish species (Browers and Stauffer, 1993). Morphometric measurements were $\log$ transferred to preserve allometrics, standardize variance and produce a scale invariant covariance matrix before analysis. To ensure comprehensive analyses of the data for more powerful discrimination between populations, sheared principal components of represented morphometric measurements were scattered against the first principal components in SPSS (V.14.0).

\section{DNA isolation and PCR}

The DNA was isolated by standard Proteinase-K/Phenol-Chloroform-ethanol method (Sambrook et al., 1989) and the concentration of isolated DNA was estimated us- ing a UV spectrophotometer. The DNA was diluted in TE buffer to a final concentration of $100 \mathrm{ng} / \mu \mathrm{L}$. Ten commercially available decamer random primers $(A n 1-A n 10)$ from Chromous Biotech Pvt Ltd (Bangalore, India) were used for this study. The amplification reaction was carried out in a $25 \mu \mathrm{L}$ reaction volume containing $10 \mathrm{mM}$ Tris-HCl, $50 \mathrm{mM} \mathrm{KCl}$ ( $\mathrm{pH}$ 8.5), $2.5 \mathrm{mM} \mathrm{MgCl}, 0.001 \%$ gelatin, $100 \mu \mathrm{M}$ of dNTP mix, $0.2 \mu \mathrm{M}$ of each primer, 1 $\mathrm{U}$ of Taq DNA polymerase (Bangalore Genei, India) and 25 ng of template DNA. The PCR was performed in a thermocycle (TechGene, UK) for 40 cycles consisting of denaturation at $94^{\circ} \mathrm{C}$ for 30 seconds, annealing at $35^{\circ} \mathrm{C}$ for 30 seconds, and extension at $72^{\circ} \mathrm{C}$ for 60 seconds. The final extension was carried out at the same temperature for 5 minutes. The resulting products were electrophoretically analyzed through $1.5 \%$ agarose gels, stained with ethidium bromide, and visualized using a UV transilluminator. Subsequently the gel was photographed using a gel documentation system (Lark, India).

\section{Data analysis}

Genetic similarity/distance between the three stripped threadfin populations was estimated using Popgene Software (Version 1.31) (Yeh et al., 1999). Nei and Li's (1979) genetic similarity (GS) among the three populations was computed and converted by Popgene into genetic distance (GD) according to Hillis and Mortiz's (1990) formula, GD = 1-GS. The GS reflects the proportion of the bands shared between individuals and values range from (1) when present to (0) when absent. Phylogenetic relationship was estimated based on genetic distance values generated from RAPD data among the three populations. A neighbor-joining dendrogram also generated based on Nei's procedure (Nei, 1978) using Popgene.

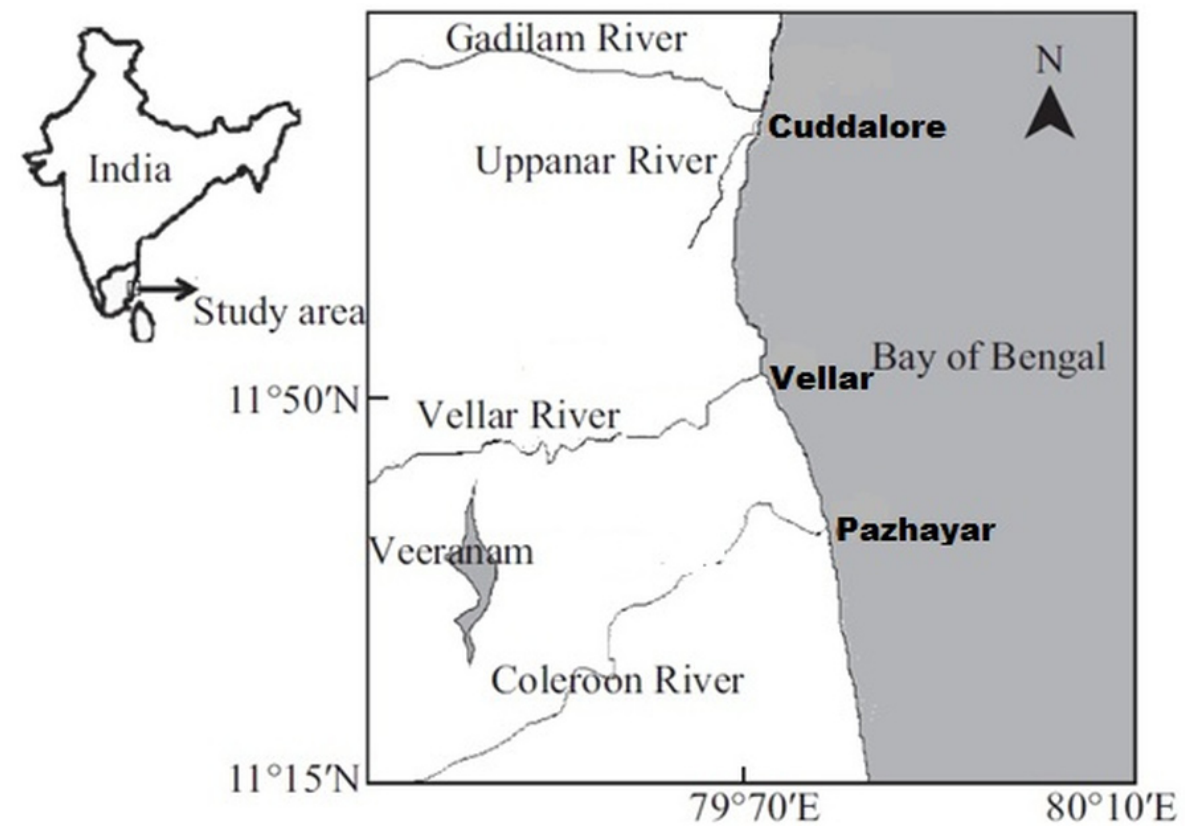

Fig. 1. Map showing the sample collection sites in Coromandel coast of India 
Differences in intrapopulation and interpopulation genetic distance coefficients among the three populations were tested by one way analysis of variance (ANOVA). Intrapopulation and interpopulation genetic distance values were compared by paired $t$-test. The statistical analyses were performed by the software SYSTAT (version 7.0).

\section{Results}

\section{Morphometrics}

Morphometric values obtained from the three populations of $P$. plebeius are shown in the Tab. 1. Many of the characters in all the three populations are not significantly deviate. Vellar and Pazhayar populations are showing more morphological similar characters value when comparing to Cuddalore population. Except total length, fork length, maximum body height, overall caudal fin length, height and length of longest pectoral fin filament, the Cuddalore population also mingled with other two populations. The principal components analysis score plot also exhibited a similar trend of clustering of Cuddalore and Pazhayar population separately. But, the Vellar population individuals are shared with Pazhayar and Cuddalore populations (Fig. 2).

\section{Genetic diversity}

By using the ten random primers $(A n 1-A n 10)$ in three populations, totally 1077 scorable bands were observed. In Cuddalore population, total numbers of bands were 330 and in Pazhayar, Vellar it was 417 and 330 respectively. Nei's (1978) unbiased genetic distances and genetic similarity between three populations of $P$. plebeius are given in Tab. 2. The genetic distance between Pazhayar and Cuddalore was more (0.0034) than Vellar and Pazhayar (0.0033). The genetic identity between Cuddalore and Pazhayar was 0.9966, genetic identity between Pazhayar and Vellar was 0.9967 based on the RAPD data. The overall observed and expected polymorphic loci in three populations are given in Tab. 3. The genetic diversity $(\mathrm{H})$ of $P$. plebeius in Cuddalore population was more $(0.0733 \pm 0.0648)$ than Pazhayar $(0.0609 \pm 0.0416)$ and Vellar $(0.0613 \pm 0.0344)$ populations. The intrapopulation genetic distance values for the three populations were tested by one way ANOVA and found to be significantly slight different $(p<0.0001)$ (Tab. 4). But the interpopulation genetic distance values estimated for the three populations also tested by one way ANOVA and found to be significantly much different $(p<0.001)$ (Tab. 4).

Score Plot

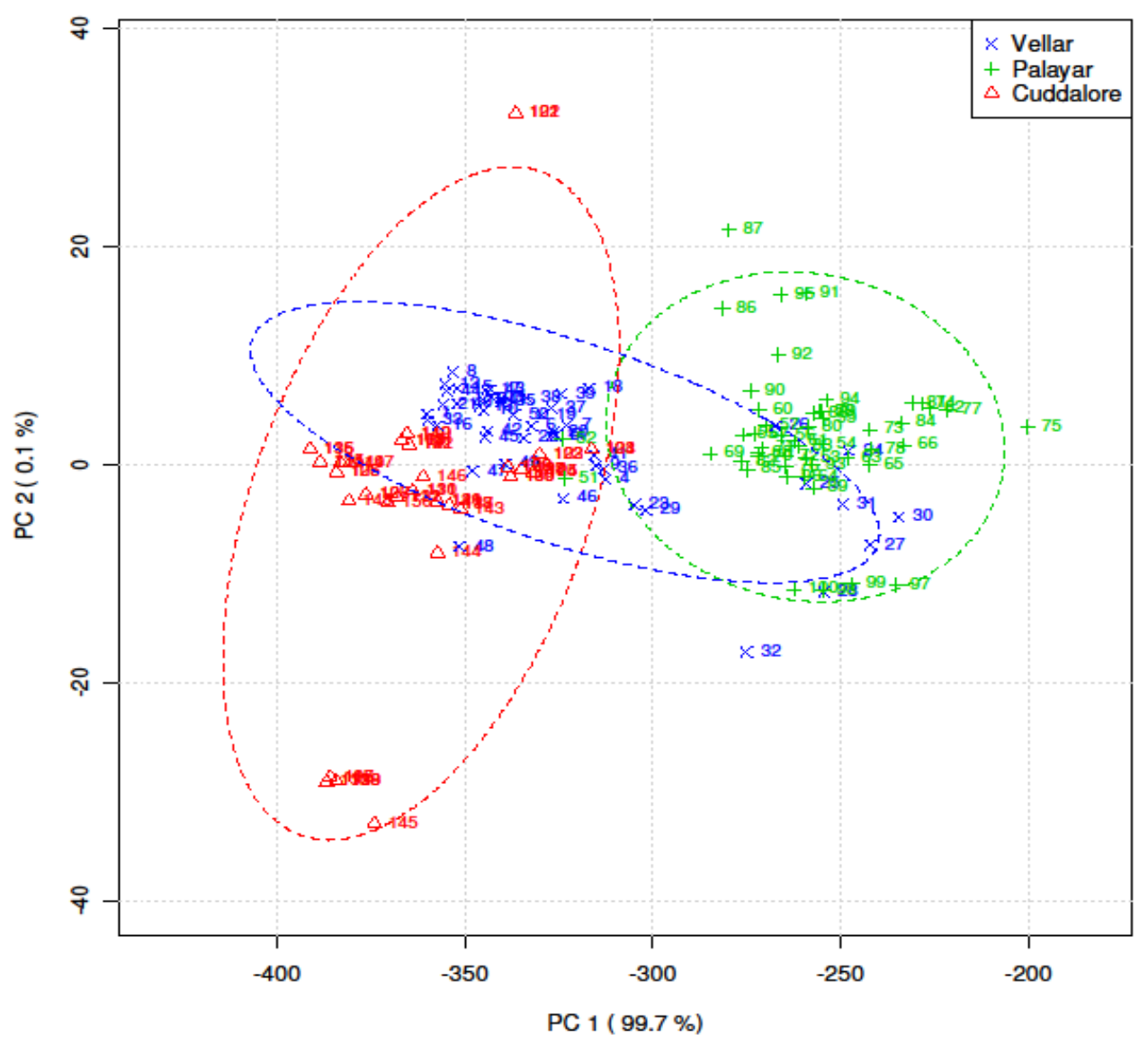

Fig. 2. Principal component score plot of morphometric data in three populations 
278

Tab. 1. Morphometric characters observed in three populations of P. plebeius

\begin{tabular}{|c|c|c|c|c|}
\hline No. & Morphometric characters (mm) & Vellar & Pazhayar & Cuddalore \\
\hline 1 & $\mathrm{TL}$ & $130 \pm 15.20^{2}$ & $156 \pm 28.1^{a}$ & $187 \pm 11.63^{a}$ \\
\hline 2 & FL & $108.7 \pm 10.26^{a}$ & $125.8 \pm 30.32^{\mathrm{b}}$ & $152.3 \pm 18.87^{\mathrm{a}}$ \\
\hline 3 & STL & $98.14 \pm 11.59^{\mathrm{a}}$ & $114.4 \pm 21.64^{\mathrm{b}}$ & $133.5 \pm 8.12^{\mathrm{a}}$ \\
\hline 4 & $1^{\text {st }}$ P-DL & $34.71 \pm 3.61^{a, c}$ & $44.4 \pm 10.42^{\mathrm{a}}$ & $44.1 \pm 2.58^{\mathrm{b}, \mathrm{c}}$ \\
\hline 5 & $2^{\text {nd }} \mathrm{P}-\mathrm{DL}$ & $61.51 \pm 3.9^{a}$ & $71.34 \pm 14.38^{b}$ & $79.3 \pm 4.92^{\mathrm{a}}$ \\
\hline 6 & P-PTL & $26.17 \pm 4.05^{\mathrm{a}, \mathrm{c}}$ & $32.25 \pm 5.78^{\mathrm{a}}$ & $37.52 \pm 2.06^{\mathrm{b}, \mathrm{c}}$ \\
\hline 7 & P-PVL & $38.37 \pm 3.33^{a, c}$ & $43.40 \pm 4.30^{\mathrm{a}}$ & $48.80 \pm 6.51^{b, c}$ \\
\hline 8 & P-AL & $63.4 \pm 5.80^{\mathrm{a}}$ & $72.96 \pm 12.94^{b}$ & $85.66 \pm 4.94^{\mathrm{a}, \mathrm{b}}$ \\
\hline 9 & $\mathrm{HL}$ & $29.37 \pm 3.13^{a, c}$ & $36.06 \pm 6.59^{\mathrm{a}}$ & $41.57 \pm 2.89^{\mathrm{b}, \mathrm{c}}$ \\
\hline 10 & $\mathrm{HH}$ & $17.97 \pm 2.8^{\mathrm{a}, \mathrm{c}}$ & $28.06 \pm 7.20^{\mathrm{a}}$ & $28.14 \pm 1.79^{\mathrm{b}, \mathrm{c}}$ \\
\hline 11 & HW & $5.25 \pm 0.56^{2 . c}$ & $6.93 \pm 1.56^{a}$ & $7.66 \pm 0.85^{\mathrm{b}, \mathrm{c}}$ \\
\hline 12 & LMC & $5.71 \pm 0.71^{a, c}$ & $7.71 \pm 2.38^{a}$ & $9.61 \pm 0.74^{b, c}$ \\
\hline 13 & LMO & $9.22 \pm 1.13^{\mathrm{acc}}$ & $11.34 \pm 2.75^{a}$ & $14 \pm 1.64^{\mathrm{b}, \mathrm{c}}$ \\
\hline 14 & UJL & $12.62 \pm 1.69^{a, c}$ & $14.15 \pm 2.12^{\mathrm{a}}$ & $14.95 \pm 0.49^{\mathrm{b}, \mathrm{c}}$ \\
\hline 15 & $\mathrm{MH}$ & $17.4 \pm 2.25^{\mathrm{a}}$ & $15.31 \pm 1.83^{a, b}$ & $19.33 \pm 2.26^{\mathrm{b}}$ \\
\hline 16 & $\mathrm{EH}$ & $12.59 \pm 1.17^{\mathrm{a}}$ & $14.56 \pm 2.15^{a}$ & $18.61 \pm 1.56^{\mathrm{a}}$ \\
\hline 17 & OD & $7.03 \pm 0.93^{\mathrm{a}}$ & $8.46 \pm 1.64^{a}$ & $10.5 \pm 0.70^{a}$ \\
\hline 18 & DEO & $3.64 \pm 0.52^{\mathrm{a,c}}$ & $4.98 \pm 0.98^{a}$ & $5.57 \pm 0.53^{\mathrm{b}, \mathrm{c}}$ \\
\hline 19 & EA & $21.64 \pm 2.83^{a}$ & $24.78 \pm 5.42^{\mathrm{b}}$ & $32.61 \pm 2.37^{\mathrm{a}, \mathrm{b}}$ \\
\hline 20 & MBH & $30.02 \pm 2.36^{a}$ & $35.21 \pm 6.72^{a}$ & $43.04 \pm 3.52^{\mathrm{a}}$ \\
\hline 21 & MBW & $5.45 \pm 0.70^{a}$ & $6.53 \pm 1.39^{\mathrm{b}}$ & $5.80 \pm 0.60^{c}$ \\
\hline 22 & B 1st-DFL & $13.85 \pm 1.71^{\mathrm{a}}$ & $16.37 \pm 3.56^{\mathrm{b}}$ & $19.19 \pm 1.99^{\mathrm{a}}$ \\
\hline 23 & $\mathrm{~B} 2^{\text {nd }}-\mathrm{DFL}$ & $19.11 \pm 2.25^{a, c}$ & $22.59 \pm 4.25^{a}$ & $25.14 \pm 1.82^{\mathrm{b}, \mathrm{c}}$ \\
\hline 24 & B-AFL & $19.82 \pm 1.82^{\mathrm{a}}$ & $21.40 \pm 3.67^{b}$ & $24.04 \pm 1.80^{\mathrm{a}}$ \\
\hline 25 & B-PTFL & $5.25 \pm 0.56^{a}$ & $5.56 \pm 0.91^{\mathrm{b}}$ & $6.95 \pm 0.66^{\mathrm{a}, \mathrm{b}}$ \\
\hline 26 & B-PVFL & $4.71 \pm 0.51^{a}$ & $4.56 \pm 0.71^{b}$ & $5.19 \pm 0.40^{c}$ \\
\hline 27 & $1^{\mathrm{st}}-\mathrm{DFH}$ & $19.4 \pm 2.58^{\mathrm{a}}$ & $23.31 \pm 4.50^{\mathrm{a}}$ & $28.61 \pm 2.29^{a}$ \\
\hline 28 & $2^{\text {nd }}-D F H$ & $18.74 \pm 2.52^{\mathrm{a}}$ & $23.40 \pm 4.17^{a}$ & $28.23 \pm 2.02^{a}$ \\
\hline 29 & AFH & $17.4 \pm 2.08^{\mathrm{a}}$ & $20.68 \pm 3.88^{a}$ & $25.33 \pm 1.90^{\mathrm{a}}$ \\
\hline 30 & PTFH & $19.34 \pm 2.38^{a}$ & $22.78 \pm 3.77^{a}$ & $27.66 \pm 2.55^{a}$ \\
\hline 31 & PVFH & $14.82 \pm 1.38^{a}$ & $16.12 \pm 2.87^{b}$ & $20.85 \pm 1.52^{\mathrm{a}, \mathrm{b}}$ \\
\hline 32 & L.L $1^{\text {st }}$-DFR & $19.4 \pm 2.58^{\mathrm{a}}$ & $23.31 \pm 4.50^{\mathrm{a}}$ & $28.61 \pm 2.29^{a}$ \\
\hline 33 & L.L $2^{\text {nd }}-D F R$ & $18.77 \pm 2.53^{a}$ & $23.40 \pm 4.17^{\mathrm{a}}$ & $28.23 \pm 2.02^{\mathrm{a}}$ \\
\hline 34 & L.L-AFR & $17.4 \pm 2.08^{\mathrm{a}}$ & $20.68 \pm 3.88^{a}$ & $25.33 \pm 1.90^{\mathrm{a}}$ \\
\hline 35 & L.L-PTFR & $19.37 \pm 2.38^{a}$ & $22.78 \pm 3.77^{a}$ & $27.66 \pm 2.55^{a}$ \\
\hline 36 & L.L-PVFR & $14.54 \pm 2.41^{\mathrm{a}}$ & $16.12 \pm 2.87^{b}$ & $20.85 \pm 1.52^{\mathrm{a}, \mathrm{b}}$ \\
\hline 37 & O $1^{\text {st-DFR-AFL }}$ & $41.82 \pm 4.05^{a}$ & $50.65 \pm 9.14^{a}$ & $62.04 \pm 4.99^{a}$ \\
\hline 38 & $\mathrm{O} 2^{\text {nd }}-\mathrm{DFR}-\mathrm{AFL}$ & $30.57 \pm 2.44^{a}$ & $35.84 \pm 6.57^{a}$ & $43.28 \pm 3.22^{\mathrm{a}}$ \\
\hline 39 & O PVFR-AFL & $27.34 \pm 3.10^{2}$ & $31.75 \pm 4.57^{\mathrm{a}}$ & $38.28 \pm 4.45^{a}$ \\
\hline 40 & $2^{\text {nd }}$ DF SPINE & $7.37 \pm 1.37^{a, c}$ & $9.65 \pm 2.29^{a}$ & $10.66 \pm 1.06^{\mathrm{b}, \mathrm{c}}$ \\
\hline 41 & L.L AF SPINE & $6.68 \pm 1.49^{\mathrm{a}}$ & $7.93 \pm 1.58^{\mathrm{b}}$ & $9.85 \pm 0.96^{\mathrm{a}, \mathrm{b}}$ \\
\hline 42 & CPL & $11.05 \pm 1.02^{\mathrm{a}}$ & $12.40 \pm 2.56^{b}$ & $12.57 \pm 1.36^{a}$ \\
\hline 43 & $\mathrm{CPH}$ & $13.31 \pm 1.40^{\mathrm{a} . \mathrm{c}}$ & $16.90 \pm 3.55^{a}$ & $19.28 \pm 1.67^{\mathrm{b}, c}$ \\
\hline 44 & CPW & $4.65 \pm 0.68^{\mathrm{a}}$ & $5.5 \pm 1.10^{\mathrm{b}}$ & $5.66 \pm 0.65^{a}$ \\
\hline 45 & UCFL & $36.28 \pm 3.34^{\mathrm{a}}$ & $40.75 \pm 7.96^{b}$ & $50.23 \pm 3.61^{a, b}$ \\
\hline 46 & LCFL & $33.31 \pm 3.48^{a}$ & $38.78 \pm 6.59^{a}$ & $46.04 \pm 3.26^{a}$ \\
\hline 47 & $\mathrm{CFH}$ & $45.65 \pm 4.56^{a, c}$ & $54.56 \pm 10.81^{a}$ & $57.42 \pm 3.13^{b, c}$ \\
\hline 48 & L.L PT F.FILAMENT & $36.05 \pm 2.36^{a}$ & $40.21 \pm 6.99^{\mathrm{b}}$ & $49.76 \pm 2.48^{\mathrm{a}, \mathrm{b}}$ \\
\hline 49 & $\mathrm{BMH}$ & $15.37 \pm 1.43^{\mathrm{a}}$ & $19.03 \pm 3.76^{\mathrm{a}}$ & $23.66 \pm 2.45^{\mathrm{a}}$ \\
\hline
\end{tabular}

The common superscripts sharing the row is not significantly different $(p<0.001)$

(TL: Total length; FL: Fork length; STL: Standard length;1st. P-DL: 1st Pre-dorsal length; 2nd. P-DL: 2ndPre-dorsal length; P-PTL: Pre-pectoral length; P-PVL: Prepelvic length; P-AL: Pre-anal length; HL: Head length; HH: Head height; HW: Head width; LMC: Length of snout with mouth closed; LMO: Length of snout with mouth opened; UJL: Upper jaw length; MH: Mouth height; EH: Eye height; OD: Orbit diameter; DEO: Dermal eye opening; EA: Eye area; MBH: Maximum body height; MBW: Maximum body width; B. 1st-DFL: Base of 1st dorsal fin length; B. 2nd-DFL: Base of 2nd dorsal fin length; B-AFL: Base of anal fin length; B-PTFL: Base of pectoral fin length; B-PVFL: Base of pelvic fin length; 1st-DFH: 1st Dorsal fin height; 2nd-DFH: 2nd Dorsal fin height; AFH: Anal fin height; PTFH: Pectoral fin height; PVFH: Pelvic fin height; L. L. 1st-DFR: Length of longest 1st dorsal fin ray; L. L. 2nd-DFR: Length of longest 2nd dorsal fin ray; L. L-AFR: Length of longest anal fin ray; L. L-PTFR: Length of longest pectoral fin ray; L. L-PVFR: Length of longest pelvic fin ray; O. 1st DFL-AFL: Origin of 1st dorsal fin length to anal fin length; O. 2nd DFL-AFL: Origin of 2nd dorsal fin length to anal fin length; O. PVFL-AFL: Origin of pelvic fin length to anal fin length; 2nd DF SPINE: 2nd dorsal fin spine length; L. L. AF SPINE: Length of longest anal fin spine; CPL: Caudal peduncle length; CPH: Caudal peduncle height; CPW: Caudal peduncle width; UCFL: Upper caudal fin length; LCFL: Lower caudal fin length; CFH: Caudal fin height; L. L. PT. F. FILAMENT: Length of longest pectoral fin filament; BMH: Body mid line height) 
Tab. 2. Nei's genetic identity (above diagonal) and genetic distance (below diagonal) of three populations of P. plebeius

\begin{tabular}{cccc}
\hline Populations & Cuddalore & Pazhayar & Vellar \\
\hline Cuddalore & ${ }^{* * *}$ & 0.9966 & 0.9966 \\
Pazhayar & 0.0034 & ${ }^{* * * *}$ & 0.9967 \\
Vellar & 0.0034 & 0.0033 & ${ }^{* * *}$ \\
\hline
\end{tabular}

\section{Discussion}

As per the present study, Vellar and Pazhayar populations are close enough when compared to Cuddalore population and exhibiting low phenotypic differentiation in PCA scatter plot analysis. The obtained $p$-values denote morphometric results are insignificant to support

Tab. 3. Overall observed number of alleles ( $\mathrm{Na})$, effective number of alleles $(\mathrm{Ne})$, Nei's gene diversity $(\mathrm{H})$, Shannon's information index (I), Number of polymorphic loci ( $\mathrm{Np}$ ) and Percentage of polymorphic loci $(\mathrm{Pp})$ in three populations of $P$. plebeius

\begin{tabular}{ccccccc}
\hline Populations & $\mathrm{Na}$ & $\mathrm{Ne}$ & $\mathrm{H}$ & $\mathrm{I}$ & $\mathrm{Np}$ & $\mathrm{Pp}(\%)$ \\
\hline Cuddalore & $1.3347 \pm 0.4721$ & $1.0447 \pm 0.0832$ & $0.0733 \pm 0.0648$ & $0.1173 \pm 0.0737$ & 332 & 33.47 \\
\hline Pazhayar & $1.4183 \pm 0.4935$ & $1.0483 \pm 0.0777$ & $0.0609 \pm 0.0416$ & $0.1124 \pm 0.0839$ & 415 & 41.83 \\
Vellar & $1.3327 \pm 0.4714$ & $1.0407 \pm 0.0804$ & $0.0613 \pm 0.0344$ & $0.1107 \pm 0.0684$ & 330 & 33.27 \\
Overall & $0.0401 \pm 0.0007$ & $0.0379 \pm 0.0006$ & $0.0540 \pm 0.0317$ & 8.7672 & 1077 & 92.10 \\
\hline
\end{tabular}

Tab. 4. Summary of results of one way ANOVA to test for differences in intrapopulation and interpopulation genetic distance value calculated based on RAPD markers among the three populations

\begin{tabular}{cccccc}
\hline Source of Variation & Sum of Squares & df & Mean squares & F & P \\
\hline Within Cuddalore population & 1.0958 & 9 & 0.1217 & 12.2173 & 0.0001 \\
\hline Error & 0.0985 & 58 & 0.0896 & & \\
Total & 1.1943 & 67 & 0.2113 & & 0.0001 \\
\hline Within Pazhayar population & 1.4883 & 9 & 1.6537 & 10.2890 & \\
\hline Error & 0.0894 & 62 & 0.8903 & & \\
\hline Total & 1.5777 & 71 & 2.5440 & & \\
\hline Within Vellar population & 1.5423 & 9 & 1.7137 & 10.2362 & \\
\hline Error & 0.9225 & 55 & 0.6742 & & \\
\hline Total & 2.4648 & 64 & 2.3879 & & \\
\hline Eetween three populations & 2.9215 & 15 & 2.5632 & 34.4703 & 0.001 \\
\hline Total & 1.1264 & 561 & 0.1633 & & \\
\hline
\end{tabular}

Based on Nei's genetic distance value, an UPGMA dendrogram was constructed and given in (Fig. 3). The cluster values indicated distinct relationship between the three populations of $P$. plebeius. In this dendrogram Pazhayar and Vellar populations are closely related than Cuddalore population.

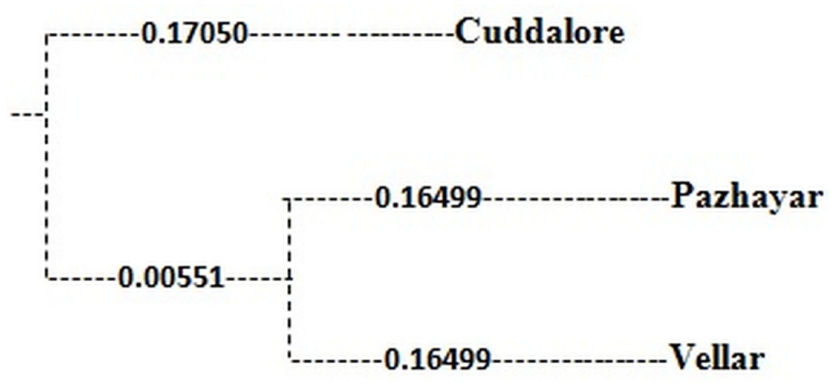

Fig. 3. Neighbour joining tree (1000 replications) generated from RAPD data of the three populations the established differentiation between these three populations that often leads to taxonomic uncertainity. Some of the Pazhayar individuals clustered with Vellar population and some individuals clustered in a separate place in the plot. Only some individuals in Vellar population placed in between the Cuddalore and Pazhayar populations and remaining all the individuals dropped in a separate cluster in the plot.

The close distribution of these samples may be accounted for recent separation due to ecological alterations. Discrimination of the three populations as a single entity could be confirmed statistically by the insignificant difference observed from the morphometric data. Turan et al. (2006) studied the morphological variation of Pomatomus saltatrix based on morphometric and meristic analyses of samples collected throughout the Black Sea, Marmara, Aegean and eastern Mediterranean Seas and the results indicated existence of three morphologically differentiated groups. Erguden et al. (2009) underwent morphometric and meristic analyses of chub mackerel, Scomber japonicus throughout the Black, Marmara, Aege- 
280

an, and northeastern Mediterranean Seas. They observed a clear pattern of morphometric and meristic differentiation between the stocks. The present study also showed a clear pattern of differentiation between the stocks and revealed two groups, the southern estuary stock (Pazhayar) and the northern estuary stock (Cuddalore).

The RAPD profile showed $92.10 \%$ polymorphic loci among the three estuarine populations in this study. As compared to previous studies, $68 \%$ of polymorphic loci were reported in three populations of catfish, Clarias batrachus in three water bodies of Bhopal in India (Mehrotra et al., 2010). Rahman et al. (2009) studied genetic variations of wild and hatchery populations of Catla catla revealed by RAPD markers and found overall $54.55 \%$ polymorphism. Shifat et al. (2003) have also reported RAPD Jaccards dissimilarity coefficient in 34 individuals of Tenualosa ilisha and observed $20.41 \%$ polymorphism. Rajasekar et al. (2012) investigated that the RAPD profile showed $93.12 \%$ polymorphic loci among the three populations of Lates calcarifer. The present study inferred from these RAPD data that showed relatively high level (92.10\%) of genetic polymorphism and is possibly due to the small sampling size.

While considering the Nei's gene diversity $(\mathrm{H})$, it was high $(0.0733 \pm 0.0648)$ in Cuddalore population compared to the Vellar $(0.0613 \pm 0.0344)$ and Pazhayar $(0.0609 \pm 0.0416)$ populations, which are more or less similar. This result also coincides with previous study revealed by RAPD marker, where Nemipterus nemurus $(0.0652 \pm 0.0520)$ showed similar gene diversity than $N$. cyanomus $(0.0354 \pm 0.0208)$ and $P$. caeruleus $(0.0283 \pm$ 0.0197) (Parveen et al., 2011). Their results illustrate that genetic structure of damselfish population differ upon at the genus level not at the species level.

Nei's genetic identities between the three populations were high and it is evident that those three distinct populations were recently isolated or they are inhabited with weak geographical barriers. Similar genetic identity and genetic distance values were observed in the genetic diversity analysis of two Gangetic riverine populations of Eutropiichthys vacha using RAPD (Chandra et al., 2010). They confirmed eventhough these two riverine populations vary spatially but originate from the same drainage system. In theory, the intrapopulation genetic distance values are expected to be lower than the interpopulation genetic distance. In this study also all the three populations had significantly $(p<0.001)$ higher interpopulation genetic distance value than the intrapopulation value.

The clustering pattern obtained by UPGMA method both the Pazhayar and Vellar populations were fell in one clade and Cuddalore population displayed in another clade. This clustering pattern is directly propotional to the geographical distance. The same type clustering pattern regarding the geographic distance was obtained with the RAPD profiling analysis study on wild fish populations of Catla catla, Eutropiichthys vacha, Clarias batrachus, Tenu- alosa ilisha and Lates calcarifer (Shifat et al., 2003; Rahman et al., 2009; Chandra et al., 2010; Mehrotra et al., 2010; Rajasekar et al., 2012).

\section{Conclusions}

Statistical inference on morphometric data in this study revealed that it is insignificant to consider all three fish populations are widely distinct. RAPD gene diversity indices and genetic identity and distance values go accordingly same as mentioned with morphometric data. This was again corroborated with PCA and scatter plot analysis as well as dendrograms structured using UPGMA method. From the inferences claimed with previous studies in other fishes, it is feasible to consider all three populations as a single genetic structure. This presumption could be authenticated henceforth with other molecular markers. Further molecular studies, comprising more markers with other populations are still required to precisely evaluate the genetic structure of threadfin fishes along the Indian coast.

\section{Acknowledgements}

The authors are grateful to the University Authorities, The Director, CAS in Marine Biology, Annamalai University for the encouragement and facilities provided.

\section{References}

Bardakci F, Skibinski DOF (1994). Application of the RAPD technique in tilapia fish: species and subspecies identification. Heredity 73:117-123.

Bookstein FL, Chernoff B, Elder RL, Humphries JM, Smith GR, Strauss RE (1985). Morphometrics in evolutionary biology: the geometry of size and shape change, with examples from fishes. Philadelphia 15:277.

Bronte CR, Fleischer GW, Maistrenko SG, Pronin NM (1999). Stock structure of Lake Baikal omul as determine by wholebody morphology. J Fish Biol 54:787-798.

Brown B, Epifanio J (2003). Nuclear DNA, 101-123 p. In: Hallerman EM (Ed.). Population genetics: principles and applications for fisheries scientists. American Fisheries Society, Bethesda, Maryland.

Carvalho GR, Hauser I (1994). Molecular genetics and the stock concepts in fisheries. Rev Fish Biol Fish 4:326-350.

Chandra G, Saxena, Barat A (2010). Genetic diversity of two riverine populations of Eutropiichthys vacha (Hamilton, 1822) using RAPD markers and implications for its conservation. J Mol Biol 8:77-85.

Erguden D, Ozturk B, Erdogan ZA, Turan C (2009). Morphologic structuring between populations of chub mackerel Scomber japonicus in the Black, Marmara, Aegean, and Northeastern Mediterranean Seas. Fish Sci 75:129-135.

Hadrys H, Balick M, Schierwater B (1992). Applications of random amplified polymorphic DNA (RAPD) in molecular 
ecology. Mol Ecol 1:55-63.

Hillis DM, Moritz C (1990). An overview of applications of molecular systematics, 502-515 p. In: Hillis DM, Moritz C (Eds.). Molecular systematics. Sinauer Associates Sunderland, Massachusetts.

Joseph J, Jeyasankar P (2001). Mophometric and genetic variations in the threadfin bream Nemipterus mesoprion. J Mar Biol Ass India 43 (1\&2):217-221.

Kagwade PV (1970). The polynemid fishery of India. Bull CMFRI 18:1-69.

Lu R, Rank GH (1996). Use of RAPD analyses to estimate population genetic parameters in the alfalfa leaf-cutting bee, Megachile rotundata. Genome 39:655-663.

Mehrotra NN, Garg RKP, Sairkar N, Silawat, Batav V (2010). Assessment of genetic diversity of Clarias batrachus using RAPD markers in three water bodies of Bhopal. J Env Biol 31:749-753.

Motomura H, Iwatsuki Y, Kimura S, Yoshino T (2001). Revision of the Indo-West Pacific polynemid fish genus, Eleutheronema (Teleostei: Perciformes). Icht Res 49:47-61.

Nei M (1978). Estimation of Average hetrozygosity and genetic distance from a small number of individuals. Genetics 89:583-590.

Nei M, Li WS (1979). Mathematical model for studying genetic variation in terms of restriction endonucleases. PNAS USA $76: 5269-5273$.

Parveen EJ, Thangaraj M, Ajith Kumar TT, Bhimba BV, Rajasekar M (2011). RAPD probe on genetic variation in damselfishes (Family: Pomacentridae) in Gulf of Mannar region. Asian J Exp Biol Sci 2:687-690.

Prasad RR, Jaiswar AK, Reddy SB, Chakraborty SK, Palaniswamy R, Parida P (2005). Growth, mortality and yield per recruit of Polynemus heptadactylus (Cuvier) (Teleostei: Polynemidae) from Mumbai waters, India. Fish Res 76:155161.
Rahman SMZ, Khan M, Islam SAS (2009). Genetic variation of wild and hatchery population of the catla India major carp (Catla catla Hamilton, 1822: Cypriniformes, Cyprinidae) revealed by RAPD markers. Gen Mol Biol 32:197-201.

Rajasekar M, Thangaraj M, Barathkumar TR, Subburaj J, Muthazhagan K (2012). Genetic diversity analysis of Lates calcarifer (Bloch 1790) in captive and wild populations using RAPD markers. Not Sci Biol 4(3):33-37.

Sambrook J, Fritsch EF, Maniatis T (1989). Molecular cloning: A laboratory manual, $2^{\text {nd }}$ Edn. Cold Spring Harbor Laboratory Press, Cold Spring Harbor, New York.

Shifat R, Begum A (2003). Use of RAPD fingerprinting for discriminating two populations of Hilsa shad (Tenualosa ilisha Ham) from Inland Rivers of Bangladesh. J Biochem Mol Biol 36:462-467.

Srinath M, Balan K (2003). Potential yield from Indian EEZ, 286-298 p. In: Joseph Mohan M, Jayaprakash AA (Eds.). Status of Exploited Marine Fishery Resources of India.

Swain DP, Foote CJ (1999). Stocks and chameleons: the use of phenotypic variation in stock identification. Fish Res 43:1123-1128.

Turan C, Oral M, Ozturk B, Duzgunes E (2006). Morphometric and meristic variation between stocks of Bluefish (Pomatomus saltatrix) in the Black, Marmara, Aegean and northeastern Mediterranean Seas. Fish Res 79:139-147.

Ward RD, Grewe PM (1994). Appraisal of molecular genetic techniques in fisheries. Rev Fish Biol Fish 4:300-325.

Yeh FC, Yang RC, Boyle T (1999). POPGENE 32-Version 1.31. Population genetics software. 